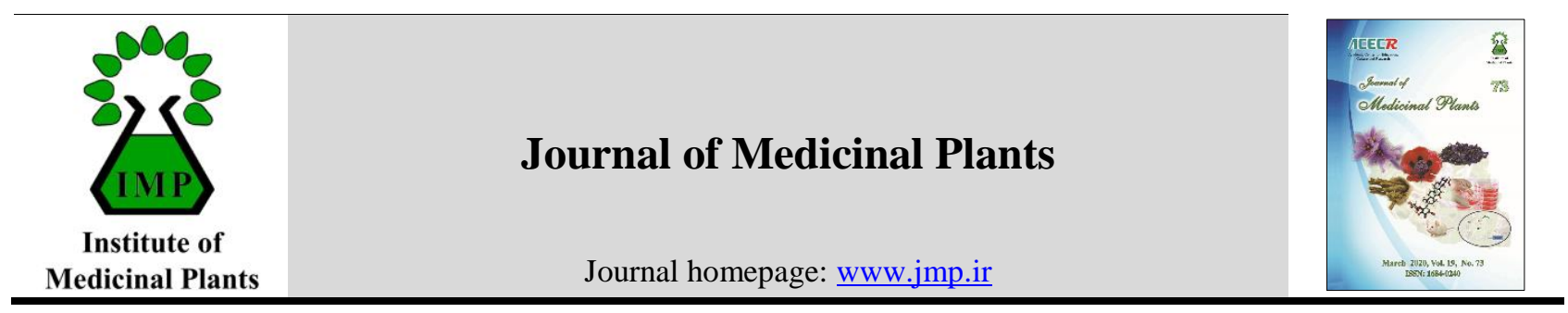

Research Article

\title{
Dietary supplementation with Salvia officinalis $L$. and aerobic training attenuates memory deficits via the CREB-BDNF pathway in amyloid beta- injected rats
}

\author{
Iman Mohseni, Maghsoud Peeri*, Mohamad Ali Azarbayjani
}

Department of Exercise Physiology, Faculty of Physical education and Sport Sciences, Central Tehran Branch, Islamic Azad University, Tehran, Iran

\begin{tabular}{|c|c|}
\hline ARTICLE INFO & ABSTRACT \\
\hline $\begin{array}{l}\text { Keywords: } \\
\text { Salvia officinalis L. } \\
\text { Alzheimer's disease } \\
\text { Hippocampus } \\
\text { Treadmill }\end{array}$ & $\begin{array}{l}\text { Background: AD is a neurodegenerative disorder in which there is a gathering } \\
\text { of beta-amyloid plaques, primarily in the hippocampus, that lead to neuronal } \\
\text { death. Exercise training and botanical medications can play a role in the } \\
\text { prevention and treatment of neurodegenerative disorders. Objective: The aim of } \\
\text { this study was to determine the effects of aerobic training and Salvia officinalis } \\
\text { extract on the improvement of learning and memory deficits in amyloid beta - } \\
\text { injected rats. Methods: Rats were injected with an A } \beta \text { solution into the CA1 } \\
\text { hippocampal region. Rats were then exposed to treadmill exercise and } \\
S \text {. officinalis extract for } 4 \text { weeks, at which point they performed the MWM. } \\
\text { Additionally, we studied the molecular factors involved in neuronal plasticity, } \\
\text { such as CREB and BDNF. The animals were also evaluated histologically to } \\
\text { determine the deposition of A } \beta \text { in the brain tissue. Results: The results showed } \\
\text { that aerobic training and } S \text {. officinalis improved learning and memory in the } \\
\text { behavioral test. The results of the molecular analysis showed that CREB and } \\
\text { BDNF levels were attenuated in the A } \beta \text {-injected rats in comparison with the } \\
\text { control group. The density of surviving neurons was considerably higher in the } \\
\text { training-extract-A } \beta \text { group (P }<0.01 \text { ) and extract-A } \beta \text { group (P<0.05) than the } \\
\text { negative control groups. Conclusion: In the present study, behavioral testing and } \\
\text { biochemical analysis demonstrated that aerobic training and } S \text {. officinalis extract } \\
\text { treatment for } 4 \text { weeks protects against memory deficits in A } \beta \text {-injected rats. }\end{array}$ \\
\hline
\end{tabular}

\section{Introduction}

Alzheimer's disease is the most common neurodegenerative disease and is characterized by the deposition of Amyloid beta plaques in the brain [1], gathering of intracellular neurofibrillary tangles, synaptic loss, and neuronal cell death. Studies have shown that soluble oligomers of $A \beta$ have neurotoxic effects [2] and lead to neuronal apoptosis well as learning and memory deficits. CREB is a

Abbreviations: AD, Alzheimer's disease; Aß, Beta-amyloid; MWM, Morris water maze test; CREB, Ca2+/cAMPresponse element binding protein; BDNF, Brain-derived neurotrophic factor

* Corresponding author: m.peeri@iauctb.ac.ir

doi: 10.29252/jmp.1.73.119

Received 8 November 2018; Received in revised form 7 January 2019; Accepted: 8 January 2019

(C) 2020. Open access. This article is distributed under the terms of the Creative Commons Attribution-NonCommercial 4.0 International License (https://creativecommons.org/licenses/by-nc/4.0/) 
transcription factor that has long been considered a critical factor in the molecular basis of learning and memory [3, 4, 5]. A $\beta$ inhibits CREB phosphorylation and cell proliferation in the hippocampus of transgenic mice [6].

Previous studies have shown that exercise training leads to an increase in CREB and BDNF gene expression [7, 8, 9]. The intensity and duration of exercise $i \mathrm{~s}$ important in the regulation of these genes $[10,11,12]$. As well, strength and aerobic training can produce similar or different effects on CREB or BDNF gene expression [13, 14, 15]. One of the most important signaling pathways in the brain is the binding of BDNF to its specific receptor in various regions of the hippocampus [16]. The binding of BDNF to its receptor leads to activation of several signaling pathways, including PKC, MAPK, and CREB [17, 18, 19]. Studies have shown that changes in BDNF signaling are necessary to produce the effects of exercise training on the formation of the hippocampus. Further, BDNF signaling can attenuate neuronal plasticity; blockade of this signaling pathway inhibits the memory and learning improvements cause by exercise training in rodents [20]. Even a single training session can lead to an increase in BDNF levels [21].

Salvia officinalis L. has antioxidant properties due to its polyphenolic compounds, and studies have shown that phenolic components increase neuronal development and protection [22, 23]. Previous studies have suggested that salvia extract increases CREB phosphorylation and improves spatial memory in rats [24]. Chlorogenic acid and fluoric acid are important components of salvia extract that decrease cholinesterase activity [25, 26] .Previous studies have suggested that $1 \mathrm{mg}$ of salvia extract improves learning and memory in $A \beta$-injected rats [24]. Exercise training and dietary salvia extract are thought to activate neurogenesis via different pathways. Thus, the aim of this study was to determine the effects of exercise training and S. officinalis extract on learning and memory deficits and CREB and BDNF gene expression in $\mathrm{A} \beta$-injected rats.

\section{Materials and Methods}

\subsection{Animals}

Male Wistar rats weighing 220-240 g were obtained from the Pasteur Institute (Tehran, Iran). Rats were housed for over one week at $23 \pm 1{ }^{\circ} \mathrm{C}$ on a controlled 12-h light-dark cycle. Animals were housed in groups of six. Food and water were provided freely except during the brief test periods. All experiments were conducted in accordance with the Guide for the Care and Use of Laboratory Animals (National Institutes of Health Publication No. 80-23, revised 1996) and were approved by the Research and Ethics Committee of Tehran University of Medical Sciences.

\subsection{Preparation of $A \beta 1-42$ and fiber formation}

To prepare the $A \beta$, we dissolved $A \beta_{1-42}$ stock (Sigma-Aldrich, st. Louis, MO, USA) powder in phosphate-buffered saline (PBS), then made aliquots and stored them at $-20{ }^{\circ} \mathrm{C}$. A $200 \mathrm{ng} / \mu \mathrm{l}$ concentration of $A \beta$ was prepared in $\operatorname{PBS}(0.1 \mathrm{M})$. The solution of $\mathrm{A} \beta$ was incubated for 5 days at $37^{\circ} \mathrm{C}$. On the test day, PBS was added to the solution to reach a final concentration of $10 \mathrm{ng} / \mu \mathrm{l}$.

\subsection{Surgery and microinjection}

Rats were anesthetized by intraperitoneal injection of ketamine hydrochloride (Alfasan, Netherland) $(50 \mathrm{mg} / \mathrm{kg}$ ) and xylezine (Alfasan, Netherland) (4 mg/kg) and secured in a stereotaxic frame. The coordinates used for injection into the dorsal hippocampus were: anterocaudal: $-3.2 \mathrm{~mm}$ from bregma; lateral: \pm 1.8 
from bregma; and vertical: $7.2 \mathrm{~mm}$ from dura according to the atlas by Paxinos and Watson (1986). A $\beta$ was injected by means of polyethylene tubing with a $25-\mu \mathrm{g}$ Hamilton syringe. The left and right hippocampi were microinjected with $3 \mu \mathrm{l}$ of $\mathrm{A} \beta$ per side $(10 \mathrm{ng} / \mu \mathrm{l})$ into the CA1 bilaterally ( $1 \mu \mathrm{g} / \mathrm{rat})$ over one min.

\subsection{Experimental design}

Thirty-two adult male rats were assigned to one of the following groups:

Group 1 (control): microinjection of $A \beta$ into the CA1 bilaterally $(1 \mu \mathrm{g} / \mathrm{rat})$.

Group 2: microinjection of $A \beta$ into the $C A 1$ bilaterally $(1 \mu \mathrm{g} / \mathrm{rat})$ and treadmill running (30, 45 or $60 \mathrm{~min} /$ day) for 28 days.

Groups 3: microinjection of $A \beta$ into the $C A 1$ bilaterally $(1 \mu \mathrm{g} / \mathrm{rat})$ and treatment with $S$. officinalis $(100 \mathrm{mg} / \mathrm{kg} / \mathrm{day}$ by gavage, once daily) for 28 days.

Group 4: microinjection of $A \beta$ into the $C A 1$ bilaterally ( $1 \mu \mathrm{g} / \mathrm{rat})$, treadmill running $(30,45$, or $60 \mathrm{~min} /$ day) and treatment with S. officinalis (100 $\mathrm{mg} / \mathrm{kg} /$ day by gavage, once daily) for 28 days.

Due to the importance of the CREB-BDNF signaling pathway in neuroprotection, the involvement of this pathway in exercise and the neuroprotective effects caused by $S$. officinalis against $\mathrm{A} \beta$-induced disturbances were studied. Real-time reverse transcriptase polymerase chain reaction (RT-PCR) was performed to study the changes in BDNF and CREB gene expression induced by exercise and $S$. officinalis treatment. In addition, Haematoxylin and Eosin (H\&E) staining was performed to study cell density and neurodegeneration.

\subsection{Plant material}

S. officinalis was acquired from Institute of Medicinal Plants, Karaj, Iran (June 2001; voucher herbarium specimen: NPIH-2988). The plant's aerial parts were air-dried darkness. The dried plants were then powdered. The powder was stored in a dark pot at room temperature $\left(25^{\circ} \mathrm{C}\right)$. The powder was extracted by methanol four times overnight. The methanolic extract was concentrated under reduced pressure on a rotary, evaporator, then filtered and lyophilized.

\subsection{Exercise protocol}

Rats ran on a leveled motorized treadmill (Pishro Andishe sanat Co, Tehran, Iran) on week days between 9:00 am and 4:00 pm for 4 weeks. The rats were familiarized with the treadmill while it was idle. During the first two weeks, rats assigned to exercise ran on the treadmill for two $15-\mathrm{min}$ sessions at a speed of $10 \mathrm{~m} / \mathrm{min}$. During the $3^{\text {rd }}$ and $4^{\text {th }}$ weeks, rats ran for 3 and 4 sessions, respectively, at a speed of $15 \mathrm{~m} / \mathrm{min}$. A 5-min rest period was given between sessions to prevent muscle fatigue. A mild electric tingling (intensity $=0.5 \mathrm{~mA}$ ) was constantly delivered from stainless bars located at the start of each running lane to encourage reluctant rats to continue running [27].

\subsection{Behavioral test: Morris water maze (MWM)}

The maze consisted of a painted black circular pool $136 \mathrm{~cm}$ in diameter filled with water (temperature: $\sim 23{ }^{\circ} \mathrm{C}$, depth: $25 \mathrm{~cm}$ ). The pool was situated in a room with different colored visual cues on the walls. A black platform $10 \mathrm{~cm}$ in diameter was submerged in the water $(2 \mathrm{~cm}$ below the surface). The pool was conceptually divided into four quadrants with four points designed as starting positions ( $\mathrm{N}, \mathrm{S}, \mathrm{W}$, and $\mathrm{E})$. Motivation of the rat in the direction of a visible platform was evaluated by a visible platform task. The animal's position was monitored by a camera placed above the center of the pool. Animal movement was recorded by a 3CCD 
camera (Panasonic Inc., Japan) placed $2 \mathrm{~m}$ above the MWM apparatus. Locomotion tracking was evaluated using Ethovision software (version XT7) and a video tracking system for the automation of behavioral experiments (Noldus Information Technology, the Netherlands). Escape latency, distance traveled, and swimming speed were recorded during a $90 \mathrm{~s}$ window in both the probe and training trials.

\subsubsection{Habituation}

Twenty-four hours before commencing training, the rats were habituated to the pool by allowing them to perform $90 \mathrm{~s}$ of swimming in the absence of the platform.

\subsubsection{Procedure}

The behavioral tests started 28 days after the end of the protocol. The behavioral tests included a single training session consisting of four trials over four days. Each trial was started in a different quadrant of the maze. Each of the four starting positions was used twice during the four training sessions in a random order. During each trial, the rat was given $90 \mathrm{~s}$ to find the hidden platform. After finding the platform, the animals were allowed to remain on the platform for $30 \mathrm{~s}$, and then were placed in a holding cage for $30 \mathrm{~s}$ until the start of next trial. When training was complete, the animals were returned to their home cages until the probe trial, which started 24 $\mathrm{h}$ later (on the test day). In the probe trial, the hidden platform was removed and the animals were released from a fixed location $(\mathrm{N})$ and allowed to swim freely for $90 \mathrm{~s}$. All experiments were conducted between 9:00 AM and 1:00 PM.

\subsection{Real-time reverse transcriptase polymerase chain reaction ( $R T-P C R)$}

Total RNA was extracted from $200 \mu \mathrm{g}$ of hippocampus tissue using ONE STEP-RNA reagent (Bio Basic, Markham, Ontario, Canada Inc.) according to the manufacturer's instructions. Extracted RNA was assessed for quantity and quality using a nanodrop (ND-1000, Thermo Scientific Fisher, USA) and gel electrophoresis, respectively. To eliminate genomic contamination, RNA was treated with DNase I (Qiagen, Hilden, Germany) per the manufacturer's instructions. Next, complementary DNA (cDNA) was synthesized using $1 \mu \mathrm{g}$ of total RNA. The integrity and quality of the cDNA was examined using a glyceraldehyde 3-phosphate dehydrogenase (GAPDH) primer as the housekeeping gene. RTPCR was carried out to evaluate the differences in expression patterns of the BDNF and CREB genes among the experimental groups. The primers were designed using Primer 3 software version 0.4 (frodo.wi.mit.edu) (Table 1).

Real-time RT-PCR was performed in $20-\mu 1$ reactions containing $1 \mu \mathrm{l}$ of cDNA target, 100 $\mathrm{nM}$ of each the forward and reverse primers, and 1 X SYBR1 ${ }^{\circledR}$ Premix Ex Taq $^{\mathrm{TM}}$ II (Takara, Tokyo, Japan). Experiments were carried out in triplicate using a CFX96 ${ }^{\mathrm{TM}}$ Real-Time System (C1000TM Thermal Cycler; Bio-Rad, Hercules, CA, USA).The amplification conditions were as follows: initial denaturation at $95^{\circ} \mathrm{C}$ for $10 \mathrm{~min}$ followed by 40 cycles (denaturation at $95{ }^{\circ} \mathrm{C}$ for $15 \mathrm{~s}$, annealing and extension at $60^{\circ} \mathrm{C}$ for $1 \mathrm{~min}$ ). The relative values of the mRNA expression of the CREB and BDNF genes were calculated by comparing the cycle thresholds (CTs) of the target genes with that of the housekeeping gene (GAPDH) using the $2-\Delta \Delta \mathrm{C}_{\mathrm{T}}$ method and REST 2009 software [28]. Serial dilutions of the cDNAs were used for calculation of the primer set efficiencies in real-time PCR. 
Table 1. RT-PCR primers

\begin{tabular}{cc}
\hline Genes & Primer sequences \\
\hline \multirow{2}{*}{ BDNF } & $\begin{array}{c}\text { Forward: 5'-GGAGGCTAAGTGGAGCTGAC-3' } \\
\text { Reverse: 5'-GCTTCCGAGCCTTCCTTTAG-3' }\end{array}$ \\
\hline \multirow{2}{*}{ CREB1 } & $\begin{array}{c}\text { Forward:5'-CAGACAACCAGCAGAGTGGA-3' } \\
\text { Reverse: 5'-CTGGACTGTCTGCCCATTG-3' }\end{array}$ \\
\hline \multirow{2}{*}{ GAPDH } & Forward : 5'-AGACAGCCGCATCTTCTTGT-3' \\
& Reverse: 5'-CCGTTCACACCGACCTTCA-3' \\
\hline
\end{tabular}

\subsection{Histopathology}

The animals were euthanized after 28 days of treatment and 5 days of behavioral testing. The harvested brain tissues were fixed in $10 \%$ neutral buffered formalin (NBF, $\mathrm{pH} 7.26$ ) for $48 \mathrm{~h}$, then processed and embedded in paraffin. Five $\mu \mathrm{m}$ thick sections were prepared and stained with Haematoxylin and Eosin (H\&E) staining. An independent reviewer evaluated the slides using light microscopy (Olympus BX51; Olympus, Tokyo, Japan). The slides were assessed for histological changes, including inflammatory responses, neuronal degeneration, hemorrhage, and hyperemia.

\subsection{Data analysis}

Data are expressed as the mean \pm SEM (standard error of the mean). Data analysis, was performed using SPSS software (version 17). For the behavioral testing and molecular studies, two-way analysis of variance (ANOVA) and two-way repeated measures ANOVA followed by post hoc Bonferroni analysis were used. A $\mathrm{P}$-value less than $0.05(\mathrm{P}<0.05)$ was considered statistically significant $(* \mathrm{P}<0.05, * * \mathrm{P}<0.01$, and $* * * \mathrm{P}<0.001)$.

Journal of Medicinal Plants

\section{Results}

\subsection{Behavioral results}

3.1.1. Aerobic training and Salvia officinalis treatment improved spatial learning in MWM in A $\beta$-injected rats

We used the MWM test to test spatial learning and memory because it is more useful than other test apparatuses. The data obtained in the training session showed a significant difference between the first and fourth day in escape latency and distance traveled in all experimental groups ( $\mathrm{P}<0.01$; Fig. 1A and 1B). The swimming speed did not show any significant change between the first and fourth day training trials, indicating that there was no motor disturbance in the treated animals ( $\mathrm{P}>0.05$; Fig. 1C).

\subsubsection{Aerobic training and Salvia officinalis} affected the AB-induced spatial memory impairment in $M W M$

After training the rats, we tested spatial memory impairment on the fifth day using the MWM. The statistical analysis revealed that in the probe test, the latency to the platform zone significantly increased in the training group $\mathrm{F}(1,20)=6.815 ; \mathrm{P}<0.05)$, in the extract $(100$ $\mathrm{mg} / \mathrm{kg} /$ day $)$ group $\mathrm{F}(1,20)=6.369 ; \mathrm{P}<0.05$, and there was no significant changes in the trainingextract group compared with the control group $\mathrm{F}(1,20)=3.909 ; \mathrm{P}>0.05$ (Fig. 1D). 

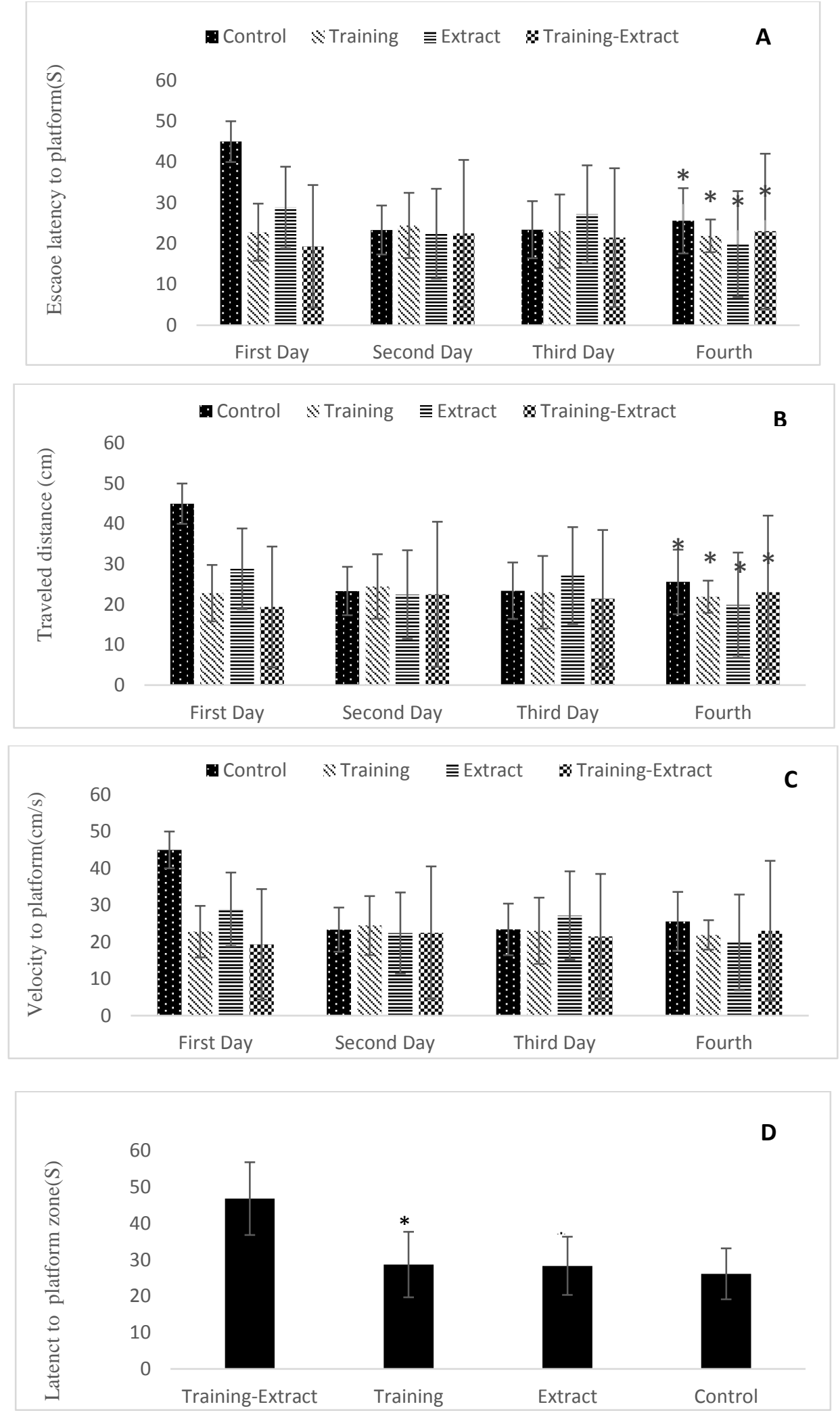

Fig. 1. Morris water maze test Results. A) Escape latency to the platform (s) over 4 days. B) Distance traveled to the platform $(\mathrm{cm})$ over 4 days. C) Velocity to platform $(\mathrm{cm} / \mathrm{s})$ over4 days. D) Latency to platform zone (s) in the probe test. 


\subsection{Molecular results}

3.2.1. Aerobic training and Salvia officinalis increased $C R E B$ gene expression in A $\beta$-injected rats

The training, extract $(100 \mathrm{mg} / \mathrm{kg} /$ day $)$, and training-extract groups had higher CREB gene expression in the CA1 region of the hippocampus than the control group $(\mathrm{P}<0.001)$ (Table 2).

\subsubsection{Aerobic training and Salvia officinalis increased} $B D N F$ gene expression in $A \beta$-injected rats

The training, extract $(100 \mathrm{mg} / \mathrm{kg} / \mathrm{day})$, and training-extract groups had higher BDNF gene expression in the CA1 region of the hippocampus than the control group $(\mathrm{P}<0.001)$ (Table 2).

\subsection{Histopathological Results}

\subsubsection{Aerobic training and Salvia officinalis} increased the density of the surviving neurons in A $\beta$-injected rats

The Hematoxylin and Eosin $(\mathrm{H} \& \mathrm{E})$ sections from the different experimental groups were evaluated histologically to determine the deposition of $A \beta$ in the brain. The control (C) group showed morphological signs of necrosis, including cytoplasmic swelling of neurons, various degrees of vacuolization, numerous indistinct and dark cells and necrotic cells (Fig. 2C). In addition, the organization of the hippocampus CA1 neuronal layer was generally disrupted.

The histopathologic findings of the training (T) group showed lesions similar to the negative control (C) group, with dark-stained or a lack of a visible cell boundary in the hippocampal CA1 areas (Fig. 2T). Micrographs of extract (E) treated animals showed that the treatment markedly attenuated the $A \beta$-induced neuronal damage, as evidenced by the fact that fewer necrotic neuronal cells were observed in the extract (E) group (Fig. 2E).

Histopathological evaluation of the trainingextract $(\mathrm{T}+\mathrm{E})$ showed a considerable reduction of $\mathrm{A} \beta$ injury in the CA1 neurons in comparison with the control (C) group (Fig. 2T+E). However, some degree of neuronal loss was still evident in this group. Treatment with training and extract appeared to have the best results in comparison with the control and other experimental groups.

Table 2. Real- time PCR results of CREB and BDNF gene expression (relative expression compared with control)

\begin{tabular}{|c|c|c|c|c|c|c|c|}
\hline Genes & Groups & Mean & $\begin{array}{c}\text { Standard Error of } \\
\text { the Mean (SEM) }\end{array}$ & $\mathbf{F}$ & df & sig & $\begin{array}{c}\text { Partial Eta } \\
\text { Squared }\end{array}$ \\
\hline \multirow{4}{*}{ CREB } & Control & 0.99769750 & 0.003988050 & - & - & - & - \\
\hline & Training & 1.51222663 & 0.006044753 & 24809.271 & 1,8 & 0.001 & 1 \\
\hline & Extract & 1.26583768 & 0.0175547815 & 16981.026 & 1,8 & 0.001 & 1 \\
\hline & $\begin{array}{l}\text { Training- } \\
\text { extract }\end{array}$ & 3.60505959 & 0.024988219 & 10142.881 & 1,8 & 0.001 & 0.999 \\
\hline \multirow{4}{*}{ BDNF } & Control & 0.00483177 & 0.000069932 & - & - & - & - \\
\hline & Training & 1.10830044 & 0.280381134 & 26.846 & 1,8 & 0.01 & 0.770 \\
\hline & Extract & 1.25727593 & 0.031569487 & 49.076 & 1,8 & 0.01 & 0.860 \\
\hline & $\begin{array}{l}\text { Training- } \\
\text { extract }\end{array}$ & 1.00014414 & 0.020796289 & 69.384 & 1,8 & 0.01 & 0.897 \\
\hline
\end{tabular}



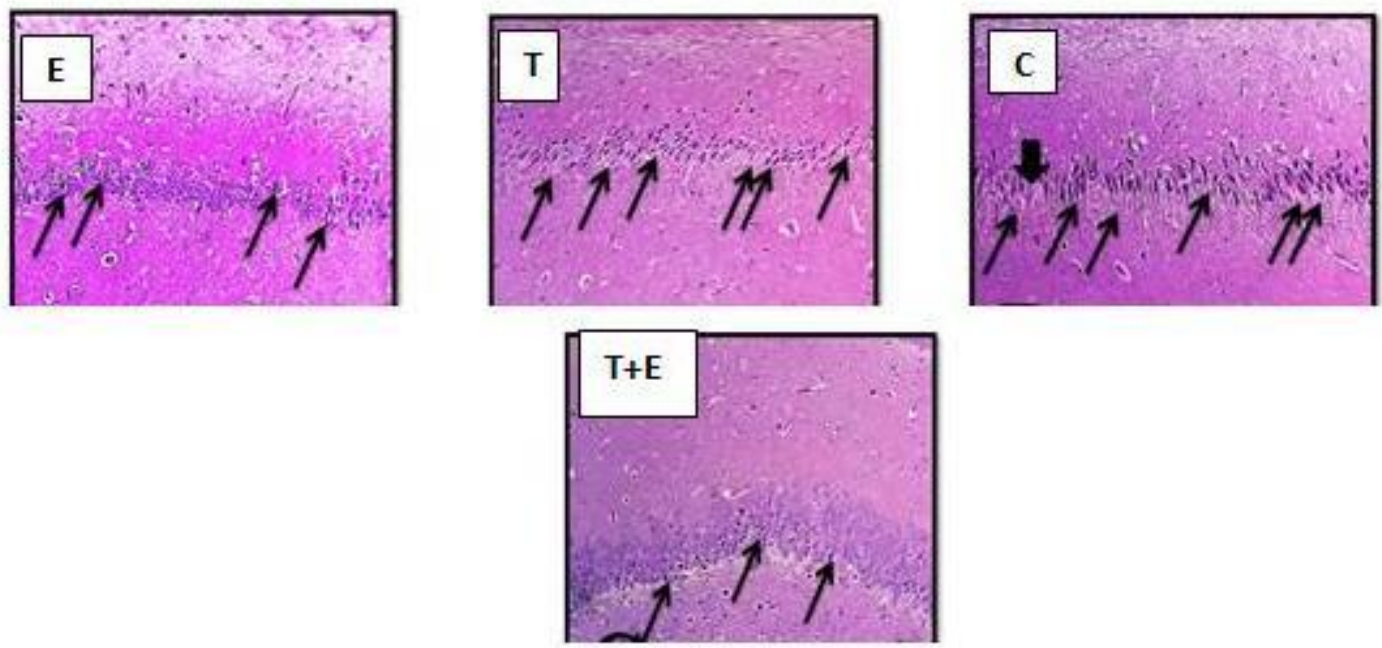

Fig. 2. Histopathologic sections of the brain in different experimental groups. $\mathrm{C}$ (control), $\mathrm{T}$ (training), $\mathrm{E}$ (extract), $\mathrm{T}+\mathrm{E}$ (training-extract), thin arrows: CA1 pyramidal neurons necrosis. Magnification: $\mathrm{x} 400$.

\section{Discussion}

$\mathrm{AD}$ is a neurodegenerative disorder that constitutes up to $75 \%$ of all dementia and cognitive impairment is one of its early symptom [29]. Using phytochemicals, such as plant extracts, in remedy of dementia was useful on different communications from ancient times. It is evaluated that more than $25 \%$ of the currently used molecules as prescribed drugs derived, directly or indirectly from plants that show the important role of plants in the development of new drugs [30]. It has been well-known that salvia species are effective on improving learning in AD in humans and animals $[31,32]$. Extract or leaves of some edible membrane of the salvia, such as S. officinalis and S. lavandulifolia are used for more than two millennia by humans to decrease and suppress cognitive decline [33].

Additionally, studies have shown that exercise decrease Alzheimer's symptoms by increasing neuronal vitality and neurogenesis $[34,35,36]$. The study of exercise in rats has shown that exercise increase spatial learning and neurodensity in the dendate gyrus of hippocampus, which leads to improvement in short-term memory [36, 37].

Additionally, studies have demonstrated that light and moderate treadmill training increases cell infiltration in juvenile rats in comparison with control animals; these studies also demonstrated that treadmill exercise increases cellular infiltration and synapses in the brain [36, 37, 38].

We assessed the effect of $S$. officinalis and aerobic training in $A \beta$-injected rats. As it has been shown that neurodegeneration cannot be found in transgenic models of amyloidosis [39].

We used the injection model. It has been previously demonstrated that injection of $A \beta$ (142) leads to brain dysfunction, which was manifested as learning and memory deficits in MWM [40].

Previous studies established that behavioral alterations emerge in 20 days after injection [41, 42].

So, the treatment protocols started 20 days after injection. Based on the obtained results, treated rats displayed lower impaired spatial learning and memories (as assessed in MWM 
task), which is regarded as a good indicator of hippocampal function [42].

The amelioration of cognitive deficits has been shown for other membrane of sage family, such as S. lavanduaefolia, S. sahendica and other exercise training as well [32, 43, 36, 37].

As mentioned, one of the major symptoms of $\mathrm{AD}$ is cognitive disorder and memory loss.

Several cascades involved in memory formation are impaired in AD. CREB is a transcription factor that has been long considered as a critical molecular basis of learning and memory. This molecule plays its pivotal role in early process of long term memory and neuronal plasticity through c-fos, whose upregulation associates with spatial and behavioral learning and memory in rats $[3,4,5]$.

We found that dietary supplementation of, $S$. officinalis and aerobic training increased CREB expression in $\mathrm{A} \beta$-injected rats. Beside, based on our results $S$. officinalis and aerobic training increased Brain-derived neurotrophic factor (BDNF) expression in $\mathrm{A} \beta$-injected rats.

BDNF, an important nerve growth factor, plays a vital role in synaptic plasticity, neurogenesis and neuronal survival [44].

BDNF and its receptor, tropomyosin related kinase $\mathrm{B}$, are regulated by CAMP and CREB. Furthermore,CREB-BDNF signaling has been implicated in regulating several neural functions like learning, memory, mood balance and reward mechanisms [45].

Regular modest level of physical activity improves mitochondrial function through several mechanisms such as increasing mitochondrial biogenesis and glucose transport (BDNF), elimination of damaged mitochondria (autophagy) and consequently inhibition of sterile inflammation by controlling mitochondrial ROS and DAMPs production [46].

the ethanolic extract of sage improves memory via the muscarinic and nicotinic systems
[31].Sage extract significantly decreased escape latency in the learning period and increased the $A \beta$-injected rats' presence in the platform zone in comparison with the control group. In molecular studies, sage has been shown to increase CREB expression in treatment groups, leading to increased memory and learning [24].

Other studies have demonstrated that BDNF increases synapsin $1 \mathrm{mRNA}, \mathrm{CREB}$ and TrkB receptors in the hippocampus. Therefore, exercise appears to have a feedback effect on BDNF expression and synaptic plasticity $[47,18]$ .Most studies have demonstrated that exercise has a positive effect on memory and learning. 2 weeks of training with 7,8-Dihydroxy flavone increased cellular- metabolism, hippocampal activity, and synaptic plasticity in the brain of injured rats [48]. Voluntary and involuntary training attenuated vascular dementia of the hippocampus and increased BDNF, PCREB,PERK $1 / 2$ in the $\mathrm{C} 1$ and $\mathrm{C} 2 / 3$ dentate gyrus in rats with vascular dementia [49]. Female ovariectomized Alzheimer's model rats following 3-months of training and found that training improved memory and learning [50] . Training significantly increased BDNF, activating CREB and APE 1 in the cerebral cortex and hippocampus of rats [51].

Training attenuated the vitality of cells in the dentate gyrus by increasing CREB phosphorylation in ischemic rats, thereby improving memory [7].

In our histopathologic study, we showed that the density of survival neurons increased in the training and extract groups in comparison with the control groups. Similar to our findings, in one study, demonstrated that drugs that contain sage risibiom attenuate the memory impairment caused by beta-amyloid plaques, similar to the effect of donepezil [52]. 
Although the present study did not address other main molecules involved in this pathway.

The molecular mechanisms underlying $A \beta$ mediated neurotoxicity still remain to be elucidated, but a great deal of investigation confirms the contribution of caspase pathway in the disease process of AD. Studies have shown the caspase- 3 activation in $\mathrm{A} \beta$-injected rats [41, 42] as well.

Many neurodegenerative disease trigger by revelation to diet or exercise [34-36, 53, 54].

So, it is imaginable that a diet and exercise training strategy maybe proper prophylactic strategy. It should be mentioned that S. officinalis supplemented diet and aerobic training were well tolerated by rats, because no significant weight loss was observed over 4 weeks of feeding and training.

\section{Conclusion}

The present results from behavioral testing and biochemical analysis demonstrated that, the combined use of aerobic training and sage extract

\section{References}

1. Jhoo JH, K.H.C, Nabeshima T, Yamada K, Shin E-J and Jhoo W-K. Beta-amyloid (1-42)induced learning and memory deficits in mice: involvement of oxidative burdens in the hippocampus and cerebral cortex. Behavioural Brain Res. 2004; 155 (2): 185-96.

2. Ladiwala AR, L.J., Kane RS, Aucoin DS, Smith SO and Ranjan S. Conformational differences between two amyloid beta oligomers of similar size and dissimilar toxicity. Biological Chem. 2003; 287 (29): 24765-73.

3. Barnes CA, S.M., Shen J and McNaughton BL. Multistability of cognitive maps in the hippocampus of old rats. Nature 1997; 388 (6639): 272-5.

Journal of Medicinal Plants have synergistic effects on neurogenic factors. Considering the inherited of S. officinalis and aerobic training, such as efficiency, fewer side effects and abundant resources make this strategy a valuable candidate for AD [55].

Future studies should focus on the other mechanisms possibly involved in this phenomenon.

\section{Author contributions}

Iman Mohseni, carried out the experiments; Maghsoud Peeri, Supervisor of the project; Mohamad Ali Azarbayjani, Consulting supervisor of the project.

\section{Conflict of interest}

The authors declare that they have no conflict of interest.

\section{Acknowledgments}

Thanks to the Pharmacology Department of Tehran University of Medical Science for helping us with this study.

4. Vann SD B.M., Erichsen JT and Aggleton JP. Fos imaging reveals differential patterns of hippocampal and parahippocampal subfield activation in rats in response to different spatial memory tests. Neuroscience 2000; 20 (7): 2711-8.

5. Vann SD, Brown MW and Aggleton JP. Fos expression in the rostral thalamic nuclei and associated cortical regions in response to different spatial memory tests. Neuroscience 2000; 101 (4): 983-91.

6. Tchantchou F, Xu Y, Wu Y, Christen Y and Luo Y. EGb 761 enhances adult hippocampal neurogenesis and phosphorylation of CREB in transgenic mouse model of Alzheimer's disease. FASEB. 2007; 21 (10): 2400-8.

7. Lou S, L.J., Chang $\mathrm{H}$ and Chen $\mathrm{P}$. Hippocampal neurogenesis and gene expression 
depend on exercise intensity in juvenile rats. Brain Res. 2008; 1210: 48-55.

8. Liu YF, C.H., Wu CL, Kuo YM, Yu L and Huang AM. Differential effects of treadmill running and wheel running on spatial or aversive learning and memory: roles of amygdalar brain derived neurotrophic factor and synaptotagmin I. Physiol. 2009; 587: 3221-31.

9. Hosseini S, M.S., Kordi MR, Shabkhiz F and Fallah Omran S. Effect of short term and light forced treadmill running on BDNF and TrkB in the hippocampus of adult wistar male rats. RJMS. 2012; 19 (101): 61-7.

10. $\mathrm{Wu}$ A, Ying $Z$ and Gomez-Pinilla $F$. Omega- 3 fatty acids supplementation restores mechanisms that maintain brain homeostasis in traumatic brain injury. Neurotrauma 2007; 24: 1587-1595.

11. Seifert T, B.P., Wissenberg M, Rasmussen $\mathrm{P}$, Nordby $\mathrm{P}$ and Stallknecht B. Endurance training enhances BDNF release from the human brain. Am. J. Physiol. Regul. Integr. Comp. Physiol. 2010; 298: 372-377.

12. Molteni R, Ying $Z$ and Gómez-Pinilla $F$. Differential effect of acute and chronicexercise on plasticity-related genes in therat hippocampus revealed by microarray. Neuroscience 2002; 16: 1107-1116.

13. Suijo K, I.S., Ohya Y, Odagiri Y, Takamiya $\mathrm{T}$ and Ishibashi $\mathrm{H}$. Resistance exercise enhances cognitive function in mouse. Int. J. Sports Med. 2013; 34 (4): 368-75.

14. Lee MC1, O.M., Liu YF, Inoue K, Matsui T and Nogami H. Voluntary resistance running with short distance enhances spatial memory related to hippocampal BDNF signaling. Appl. Physiol. 2012; 113 (8): 1260-6.

Journal of Medicinal Plants
15. Ravasi AA, P.P., Kordi M R and Hedayati M. The Effects of Resistance and Endurance Training on BDNF and Cortisol Levels in Young Male Rats. Sport Biosci. 2013; 16: 49-78.

16. Aoki C, W.K., Elste A, Len G, Lin S, McAuliffe $G$ and Black IB. Localization of brainderived neurotrophic factor and TrkB receptors to postsynaptic densities of adult rat cerebral cortex. Neurosci. Res. 2000; 59 (3): 454-63.

17. Molteni R, Ying $Z$ and Gómez-Pinilla $F$. Differential effects of acute and chronic exercise on plasticityrelated genes in the rat hippocampus revealed by microarray. Eur. J. Neurosci. 2002; 16: 1107-16.

18. Vaynman S, Ying $Z$ and Gomez-Pinilla F. Interplay between brain- derived neurotrophic factor and signal transduction modulators in the regulation of the effects of exercise on synaptic plasticity Neurosci Let. 2003; 122 (3): 647-57.

19. Finkbeiner S, T.S., Maloratsky A, Jacobs KM, Harris KM and Greenberg ME. CREB: a major mediator of neuronal neurotrophin responses. Neuron 1997; 19: 1031-47.

20. Vaynman S, Ying $Z$ and Gomez-Pinilla F. Hippocampal BDNF mediates the efficacy of exercise on synaptic plasticity and cognition. Eur. J. Neurosci. 2004; 20: 2580-2590.

21. Oliff HS, B.N., Isackson $P$ and Cotman CW. Exercise-induced regulation of brain-derived neurotrophic factor (BDNF) transcripts in the rat hippocampus. Mol. Brain. Res. 1998; 61 (1-2): 147-53.

22. Rice-Evans CA, M.N. Antioxidant activities of flavonoids as bioactive components of food. Biochem. Soc. Trans. 1996; 24: 790-5.

23. Sul D, K.H., Lee D, Joo SS, Hwang KW and Park SY. Protective effect of caffeic acid against beta-amyloid-inducedneurotoxicity by the 
inhibition of calcium influx and tau phosphorylation. Life Sci. 2009; 84: 257-62.

24. Khodagholi F, A. Dietary supplementation with Salvia sahendica attenuates memory deficits, modulates CREB and its down-stream molecules and decreases apoptosis in amyloid beta-injected rats. Behav. Brain. Res. 2013; 15 (241): 62-9.

25. Clifford $\mathrm{MN}, \mathrm{Wu} \mathrm{W}$, Kirkpatrick $\mathrm{J}$ and Kuhnert N. Profiling the chlorogenic acids and other caffeic acid derivatives ofherbal chrysanthemum by LC-MSn. Agric. Food Chem. 2007; 55: 929-36.

26. Clifford $\mathrm{MN}$, Zheng $\mathrm{W}$ and Kuhnert $\mathrm{N}$. Profiling the chlorogenic acids of aster by HPLCMS (n). Phytochem. Anal. 2006; 17: 384-93.

27. Dao A.T., Zagaar M.A., Levine A.T., Salim S., Eriksen J.L. and Alkadhi K.A. Treadmill exercise prevents learning and memory impairment in Alzheimer's disease-like pathology. Curr. Alzheimer Res. 2013; 10 (5): 507-515.

28. M.W. Pfaffl, G.W.H., L. Dempfle. Relative expression software tool (REST@) for groupwise comparison and statistical analysis of relative expression results in real-time PCR. Nucleic Acids Res. 2002; 30 (9): 36.

29. Sisodia SS, M.L., Walker LC, Borchelt DR and Price DL. Cellular and molecular biology of Alzheimer's disease and animal models. Neuroimaging Clinics of North America 1995; 5 (1): 59-65.

30. PA D.S. The role of plant-derived drugs and herbal medicines in healthcare. Drugs 1997; 54 (6): 801-40.

31. Eidi M, A.E. and Massih Baharc. Effects of Salvia officinalis L. (sage) leaves on memory

Journal of Medicinal Plants retention and its interaction with the cholinergic system in rats. Nutrition 2006; 22 (3): 321-326.

32. $S, B$. Herbal medicine in the United States: review of efficacy, safety, and regulation: grand rounds at University of California, San Francisco Medical Center. Journal of General Internal Medicine 2008; 23 (6): 854-9.

33. Kennedy DO and Scholey AB. The psychopharmacology of European herbs with cognition-enhancing properties. Current Pharmaceutical Design. 2006; 12 (35): 4613-23.

34. Etnier JL. Brain function and exercise. Sport Med. 1995; 19 (2): 81-5.

35. Samorajski T, Delaney C, Durham L, Ordy JM, Johnson JA and Dunlap WP. Effect of exercise on longevity, body weight, locomotor performance and passive -avoidance memory of c57 B1/66mice. Neuro. Boil. Aging. 1985; 1: 17-24.

36. Uysal N, Tugyan K, Kayatekin BM, Acikgoz O, Bagriyanik HA, Gonenc S, Ozdemir D, Aksu I, Topcu A and Semin I. The effect of regular aerobic exercise in adolescent period on hippocampal neuron density, apoptosis and spatial memory. Neurosci. Let. 2005; 383 (3): 241-5.

37. Sim YJ, Kim SS, Kim JY, Shin MS and Kim CJ. Treadmill exercise improves short-term memory by suppressing ischemia- induced apoptosis of neuronal cells in gerbils. Neurosci. Lett. 2004; 372 (3): 256-61.

38. Churchill JD, Galvez R, Colcombe S, Swain RA, Kramer AF and Greenough WT. Exrecise, experience and the aging brain. Neurobiol. Aging. 2002; 23: 941-955.

39. Apelt J, Bigl M, Wunderlich $P$ and Schliebs R. Aging-related increase in oxidative stress correlates with developmental pattern of betasecretase activityand beta-amyloid plaque 
formation in transgenic $\operatorname{Tg} 2576$ mice with Alzheimer-like pathology. International Journal of Developmental Neuroscience 2004; 22 (7): 475-84.

40. Nitta A, Itoh $A$, Hasegawa $T$ and Nabeshima T. Beta-amyloid protein-induced Alzheimer's disease animal model. Neuroscience Letters 1994; 170 (1): 63-6.

41. Ashabi G, Ramin M Azizi P, Taslimi Z, Alamdary SZHaghparast A, Ansari N, Motamedi $\mathrm{F}$ and Khodagholi F. ERK and p38 inhibitors attenuate memory deficits and increase CREB phosphorylationand PGC-1alpha levels in Abetainjected rats. Behavioural Brain Res. 2012; 232 (1): 165-73.

42. Ramin M, Azizi P, Motamedi F, Haghparast $A$ and Khodagholi F. Inhibition of JNK phosphorylation reverses memory deficit induced by beta-amyloid (1-42) associated with decrease of apoptotic factors. Behavioural Brain Res. 2011; 217 (2): 424-31.

43. Ventura-Clapier R, Garnier A and Veksler V. Transcriptional control of mitochondrial biogenesis: the central role of PGC-1alpha. Cardiovascular Res. 2008; 79 (2): 208-17.

44. S. Dworkin, T.M. Targeting CREB signalling in neurogenesis. Expert Opin. Ther. Targets. 2010; 14 (8): 869-879.

45. S.C. Pandey, H.Z., A. Roy, K. Misra. Central and medial amygdaloid brain-derived neurotrophic factor signaling plays a critical role in alcoholdrinking and anxiety-like behaviors. J. Neurosci. 2006; 26 (32): 8320-8331.

46. Maghsoud Peeri S.A. Protective effect of exercise in metabolic disordres are mediate by inhibition of mitochondrial -derived sterile inflamation. Medicla Hypothesis 2015; 85: 707-709.
47. Kim SH, Kim HB, Jang MH, Lim BV, Kim YJ, Kim YP, Kim SS, Kim EH and Kim CJ. Treadmill exercise increases cell proliferation without Altering of apoptosis in dentate gyrus of Sprague- dawley rats. Life Sci. 2002; 71: 1331-1341.

48. Krishna G, A.R., Zhuang Y, Ying Z, Paydar A, Harris NG, Royes LF and Gomez-Pinilla F. 7,8-dihydroxyflavone facilitates the action exercise to restore plasticity and functionality: Implications for early brain trauma recovery.Biochim Biophys Acta. 2017 Jun; 1863(6): 1204-1213.

49. Lin Y, Lu X, Dong J, He X, Yan T, Liang H, Sui M, Zheng X, Liu H, Zhao J and Lu X. Involuntary. Forced and Voluntary Exercises Equally Attenuate Neurocognitive Deficits in Vascular Dementia by the BDNF-pCREB Mediated Pathway. Neurochem. Res. 2015; 40 (9): 1839-48.

50. García-Mesa Y, P.-G.H., Bonet-Costa V, Revilla S, Gómez-Cabrera MC, Gambini J, Giménez-Llort L, Cristòfol R, Viña $\mathrm{J}$ and Sanfeliu C. Physical exercise neuroprotects ovariectomized 3xTg-AD mice through BDNF mechanisms. Psychoneuroendocrinol. 2014; 45: 154-66.

51. Yang JL, Lin YT, Chuang PC, Bohr VA and Mattson MP. BDNF and exercise enhance neuronal DNA repair by stimulating CREBmediated production of apurinic/apyrimidinic endonuclease 1. Neuromolecular Med. 2014; 16 (1): 161-74.

52. Jeon S, B.S., Hur J, Jun K, Kim YK, Cho KS and Koo BS. A. modified formulation of Chinese traditional medicine improves memory impairment and reduces A $\beta$ level in the Tg-APPswe/PS1dE9 mouse model of Alzheimer's disease. Ethnopharmacol. 2011; 137 (1): 783-9. 
53. Shih AY, I.S., Barakauskas V, Erb H, Jiang $\mathrm{L}$ and $\mathrm{Li} \mathrm{P}$. Induction of the Nrf2-driven antioxidant response confers neuroprotection during mitochondrial stress in vivo. Journal of Biological Chem. 2005; 280 (24): 22925-36.

54. Mahsa Sadeghi M.P and Mir-jamal Hosseini. Adolescent voluntary exercise attenuated hippocampal innate immunity responses and depressive-like behaviors following maternal separation stress in male rats. Physiology \& Behavior. 2016; 163: 177-183.

55. Perry EK, P.A., Wang WW, Houghton $P$ and Perry NS. Medicinal plants and Alzheimer's disease: integrating ethnobotanical and contemporary scientific evidence. J. Alternative and Complementary Medicine 1998; 4 (4): 41928.

How to cite this article: Mohseni I, Peeri M, Azarbayjani MA. Dietary supplementation with Salvia officinalis L. and aerobic training attenuates memory deficits via the cREBBDNF pathway in amyloid beta- injected rats. Journal of Medicinal Plants 2020; 19(73): 119-132.

doi: $10.29252 / j m p .1 .73 .119$ 
فصلنامه كياهان دارويي

فصلنامه گياهان دارويى

مقاله تحقيقاتى

اثر تمرين هوازى وعصاره هيدرومتانلى مريم گلى (Salvia officinalis) بر حافظه، بيان CREB و BDNF در آلزايمر القا شده با بتا آميلوئيد ايمان محسنى، مقصود بيرى *، محمد على آذربايجانى

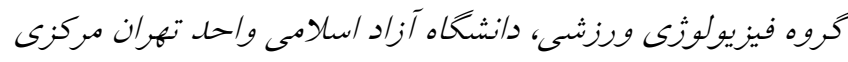

\begin{tabular}{|c|c|}
\hline جكيده & اطلاعات مقاله \\
\hline مقدمه: بيمارى آلزايمر اختلال زوال نورونى وابسته به سن بوده و تجمع آميلوئيد بتا، خصوصاً در ناحيه & 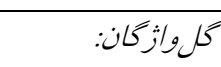 \\
\hline هييو كامٍ مهمترين علت مرك نورونها در اين بيمارى است. فعاليت بلدنى و داروهاى گياهى مىتواند در & 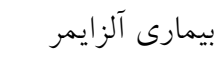 \\
\hline ييشگيرى و درمان اختلالات زوال نورونى مؤثر باشد. هدف: اين مطالعه با هدف تعيين تأثير تمرين هوازى & تردميل \\
\hline و عصاره خوراكى مريمكلى بر حافظه، بيان (CREB) و فاكتور مشتق از نوروتروفيك مغز (BDNF) در & 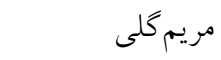 \\
\hline موشهاى صحرايى مدل آلزايمرى تيمار شده با بتا آميلوئيد، اجرا شد. روش بررسى: در يك كارآزمايى & 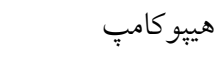 \\
\hline 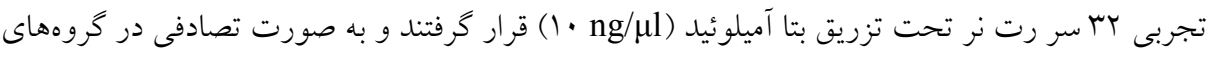 & 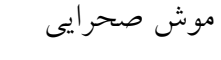 \\
\hline كتترل، تمرين هوازى، عصاره و تمرين هوازى - عصاره قرار كرفتند. يس از اب روز، كروه عصاره & \\
\hline أ عصاره مريم كلى را به صورت كاواز دريافت كردند. كروههاى تمرينى نيز جهار هفته روى & \\
\hline تردميل دويدند. بعد از اتمام دوره مداخله، از ماز آبى موريس جهت ارزيابى حافظه فضايى استفاده شد. & \\
\hline BDNF و CREB با روش Realtime PCR اندازهيرى شد و همجنين ارزيابى بافتشناسى جهت بررسى & \\
\hline ميزان تجمع دِلاكهاى بتا آميلوئيد در بافت مغز صورت گرفت. نتايج: نتايج نشان داد عصاره مريم كلى و & \\
\hline 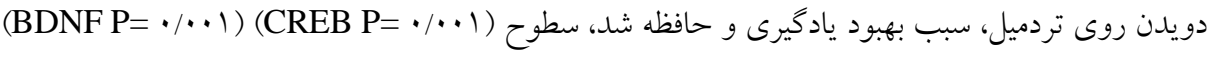 & \\
\hline در آزمودنىهاى آلزايمر القاء شده در مقايسه با گروه كتترل افزايش معنى دار يافت، جخالى سلولهاى عصبى، & \\
\hline به طور قابل ملاحظهاى در كروههاى دونده روى تردميل و دريافتكننده عصاره نسبت به گروه كنترل & \\
\hline 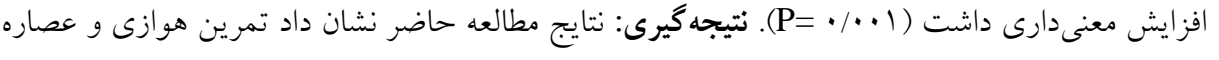 & \\
\hline مريم كلى اثر همافزايى بر بهبود حافظه، نقص عصبى و ״حكالى سلولهاى عصبى در شرايط آلزايمر القا شده & \\
\hline با بتا آميلوئيد دارد. لذا استفاده همزمان اين دو مداخله بيشنهاد مىشود. & \\
\hline
\end{tabular}

مخغفنها: Bain-derived neurotrophic factor (BDNF) Ca2+/cAMP-response element binding protein (CREB) m.peeri@iauctb.ac.ir :نويسنده مسؤول: *

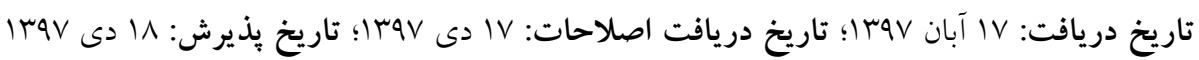
doi: 10.29252/jmp.1.73.119

(C) 2020. Open access. This article is distributed under the terms of the Creative Commons Attribution-NonCommercial 4.0 International License (https://creativecommons.org/licenses/by-nc/4.0/) 